\title{
Carnobacterium maltaromaticum as bioprotective culture in vitro and in cooked ham
}

\author{
Gabriela Maia Danielski ${ }^{\mathrm{a}, \mathrm{b}}$, Pedro Henrique Imazaki ${ }^{\mathrm{b}}$, Caroline Maria de Andrade Cavalari ${ }^{\mathrm{a}}$, \\ Georges Daube $^{\mathrm{c}}$, Antoine Clinquart ${ }^{\mathrm{b}}$, Renata Ernlund Freitas de Macedo ${ }^{\mathrm{a}, *}$ \\ ${ }^{a}$ Laboratory of Agrifood Food Research and Inovation (LAPIAgro), Graduate Program in Animal Science, School of Life Sciences, Pontifícia Universidade Católica do \\ Paraná, Imaculada Conceição, 1155, 80215-901 Curitiba, Brazil \\ ${ }^{\mathrm{b}}$ Laboratory of Food Technology, Faculty of Veterinary Medicine, Fundamental and Applied Research for Animals \& Health (FARAH), University of Liège, Avenue de \\ Cureghem 10, 4000 Liège, Belgium \\ ${ }^{\mathrm{c}}$ Laboratory of Food Microbiology, Faculty of Veterinary Medicine, Fundamental and Applied Research for Animals \& Health (FARAH), University of Liège, Avenue de \\ Cureghem 10, 4000 Liège, Belgium
}

\section{A R T I C L E I N F O}

\section{Keywords:}

Antilisterial activity

Bioprotective culture

Meat product

Lactic acid bacteria

\begin{abstract}
A B S T R A C T
The bioprotective effects of Carnobacterium maltaromaticum (CM) strains were assessed in vitro and in sliced cooked ham. CM strains were tested in vitro against Listeria monocytogenes (LM), Escherichia coli O157:H7 (EC) and Salmonella Typhimurium (ST). In vitro effect was evaluated using co-culture (with and without EDTA) and cell-free supernatant (CFS). CFS was tested by agar well diffusion and minimum inhibitory concentration. In cooked ham, the inhibitory effect of CM on L. innocua (LI) and on the physicochemical parameters were evaluated for 7 days at $4{ }^{\circ} \mathrm{C}$. In co-cultures at $-1{ }^{\circ} \mathrm{C}$ and $4{ }^{\circ} \mathrm{C}$, all CM isolates inhibited LM. A slight inhibition was observed against the Gram-negative bacteria with the addition of EDTA. CFS did not show inhibitory effect under the studied conditions. In cooked ham, CM inhibited LI growth and did not affect the physicochemical parameters of the product during storage. CM strains show potential to be used as bioprotective cultures in coldstored cooked ham and improve its safety.
\end{abstract}

\section{Introduction}

Foodborne disease outbreaks are caused by the ingestion of contaminated food with pathogenic microorganisms. The World Health Organization (WHO) considers foodborne outbreaks as critical threats to global health (WHO, 2015). In the Unites States, an estimated 9 million people get sick, 56,000 are hospitalized, and 1300 die of foodborne disease each year (IFSAC, 2019). Salmonella spp. is reported as the cause of $14 \%$ of the foodborne diseases in the European Union (EFSA \& ECDC, 2018). Other bacteria play an essential role in these outbreaks including Escherichia coli $0157: \mathrm{H7}$ and Listeria monocytogenes. These three pathogens are associated to the highest level of frequency, severity of ilnnes, hospitalizations and deaths caused by foodborne illness, linked mainly with chicken, pork and beef (EFSA \& ECDC, 2018; IFSAC, 2019).

Meat products characteristics such as high protein content, low acidity, and high-water activity make them susceptible to microbial growth (Sánchez-Ortega et al., 2014). According to the European Food Safety Authority (EFSA) and the European Centre for Disease
Prevention and Control (ECDC) (2017) in 2015, meat products were linked to the most critical cases of foodborne outbreaks in the European Union. Moreover, in Brazil, meat and meat products s were responsible for $12.8 \%$ of the outbreaks from 2009 to 2018 (Brazil, 2019). However, the frequency is probably higher than that reported due to the lack of notification of foodborne illness when the symptoms are mild, and patients do not seek medical assistance (de Oliveira, de Paula, Cardoso, \& Tondo, 2010).

The food industry has largely investigated the potential use of LAB as biopreservatives. Their inhibitory effect against pathogenic and spoilage bacteria (Alves, Martinis, Destro, Vogel, \& Gram, 2005; dos Reis et al., 2011; Hammi et al., 2016; Ho, Lo, Bansal, \& Turner, 2018; Huang, Ye, Yu, Wang, \& Zhou, 2016; Rivas, Castro, Vallejo, Marguet, \& Campos, 2014) is an important indicator of their possible use as protective cultures in food matrices, where they could replace some synthetic preservatives (Engelhardt, Albano, Kiskó, Mohácsi-Farkas, \& Teixeira, 2015; Huang et al., 2016).

Carnobacteria are ubiquitous lactic acid bacteria (LAB) isolated from cold and temperate environments and can be found as natural

\footnotetext{
* Corresponding author.

E-mail address: renata.macedo@pucpr.br (R.E.F.d. Macedo).
} 
microbiota of chilled meat, fish and dairy products. Among the 11 species of Carnobacterium, two species, Carnobacterium divergens and Carnobacterium maltaromaticum, are frequently isolated from food and show the ability to inhibit pathogenic and spoilage microorganisms in diverse food matrices (Leisner, Laursen, Prévost, Drider, \& Dalgaard, 2007). Thus, their use as bioprotective cultures in food has been considered (Iskandar et al., 2017; Orihuel et al., 2018). The antimicrobial properties of Carnobacterium spp. have been studied in vitro (Hammi et al., 2016; Tulini et al., 2014), in cold-smoked salmon (Brillet-Viel, Pilet, Courcoux, Prévost, \& Leroi, 2016), ricotta (Spanu et al., 2018), cooked and peeled shrimp, and as a feed additive for rabbits to improve meat microbial quality and safety (Koné et al., 2018). The use of Carnobacterium spp. has also been investigated as a probiotic culture in broiler chickens (Smialek, Burchardt, \& Koncicki, 2018). However, the effect of $C$. maltaromaticum as a bioprotective culture in meat products, especially ready-to-eat products, has not been assessed.

This study aimed to evaluate the antimicrobial effect of C. maltaromaticum towards different food pathogenic bacteria in vitro and to assess the potential of its use as a bioprotective culture in cold-stored sliced cooked ham.

\section{Material and methods}

\subsection{Bacterial strains, media, and growth conditions}

Three different strains of C. maltaromaticum (CM_B824, CM_B827, and CM_B829), obtained from Australian vacuum packaged chilled beef (longissimus thoracis et lumborum) with a long shelf life (140 days at $-1{ }^{\circ} \mathrm{C}$ ) were used in this study (Imazaki et al., 2015). These strains were selected among $11 \mathrm{CM}$ strains after the sequencing of their genome, which revealed the existence of three main phylogenetic groups. Therefore, one strain of each group was selected to be used in the present study.

Foodborne pathogenic bacteria, L. monocytogenes ATCC $^{\circledR} 19117^{\mathrm{TM}}$ (LM), E. coli O157:H7 ATCC ${ }^{\circledR} 35150^{\mathrm{TM}}$ (EC) and Salmonella Typhimurium ATCC $^{\circledR} 14028^{\mathrm{TM}}$ (ST) were used for the in vitro essay, and a pool of Listeria innocua (LI_33314, LI_33016 and LI_HPB586), isolated from meat products, belonging to the culture collection of LAPIAgro, was used as surrogate for LM in the cooked ham essay.

$\mathrm{CM}$ strains were grown in brain heart infusion (BHI) broth (Kasvi, São José dos Pinhais, Brazil) at $25{ }^{\circ} \mathrm{C}$ for $48 \mathrm{~h}$, and pathogenic and LI strains at $37^{\circ} \mathrm{C}$ for $24 \mathrm{~h}$ in the same medium. Growth was verified by optical density at $540 \mathrm{~nm}$ for the pathogenic bacteria and LI and $620 \mathrm{~nm}$ for CM (Gutiérrez, Martínez-Blanco, Rodríguez-Aparicio, \& Ferrero, 2016).

\subsection{In vitro assay}

\subsubsection{Antimicrobial effect of CM in co-culture}

The antimicrobial effect of CM in co-culture, where both CM strains and pathogens were grown together (cell-to-cell contact), was determined inoculating Falcon ${ }^{\circledR}$ flasks with $30 \mathrm{~mL}$ of BHI broth with each strain of $\mathrm{CM}$ at $6.0 \log \mathrm{CFU} / \mathrm{mL}$ in order to account for natural contamination levels and allow the enumeration of the inoculum and one of the pathogenic strains (LM, EC, ST) at $3.0 \log \mathrm{CFU} / \mathrm{mL}$. Negative controls were considered flasks with BHI inoculated with each pathogen at $3.0 \log \mathrm{CFU} / \mathrm{mL}$ and positive controls were considered flasks inoculated only with CM strains. Controls and treatments were conducted in triplicate.

Flasks were incubated at $-1{ }^{\circ} \mathrm{C}$ for 28 days, $4{ }^{\circ} \mathrm{C}$ for 14 days and $25{ }^{\circ} \mathrm{C}$ for $48 \mathrm{~h}$ in a shaker (Rotamax 120, Heidolph, Schwabach, Germany) at $150 \mathrm{rpm}$. Pathogenic bacteria counts were performed using specific chromogenic media: RAPID'L.mono, RAPID'E.coli 2 and, RAPID'Salmonella (BioRad, Marnes, France). CM population was estimated as the difference between counts on plate count agar (PCA) (BioRad, Marnes, France) and chromogenic media. The plating was also conducted in triplicate.

2.2.2. Antimicrobial effect of CM in co-culture with the addition of EDTA

The influence of the addition of ethylenediaminetetraacetic acid (EDTA) (VWR, Radnor, USA) on the effect of CM against pathogens was investigated, since this chelating agent showed synergestic interaction with bacteriocins from gram-positive bacteria targeting gram-negatives (Mathur et al., 2017). Co-cultures were carried out in flasks containing BHI broth with EDTA $1.0 \mathrm{mM}$, incubated at $25^{\circ} \mathrm{C}$ for $48 \mathrm{~h}$, in a shaker at $150 \mathrm{rpm}$. Bacterial counts were performed following the same procedure described above. To find the concentration of EDTA that would not interfere in the bacterial growth by itself, a previous experiment was conducted. Serial concentrations of EDTA (1, 5, 10, 20 and $40 \mathrm{mM})$ were added to the broth medium with each pathogen (LM, EC, ST) (Bordignon-Junior et al., 2012). The concentration that showed no difference in growth compared to negative control, inoculated broth without EDTA, was selected.

\subsubsection{Antimicrobial effect of CM cell-free supernatant (CFS) using agar well diffusion}

To check if the antimicrobial effect of CM was mediated by the production of antimicrobial molecules in the culture supernatant, three tubes containing $10 \mathrm{~mL}$ of $\mathrm{BHI}$ broth were inoculated with each $\mathrm{CM}$ strain. The tubes were incubated at $25{ }^{\circ} \mathrm{C}$ for $48 \mathrm{~h}$ and centrifuged (Model Eppendorf Centrifuge 5804, Hamburg, Germany) at 16,000 $g$ for 10 min. The supernatant of two tubes was treated with sodium hydroxide $(\mathrm{NaOH}) 1 \mathrm{M}$ (VWR, Radnor, USA) until pH 6.5 to neutralize antimicrobial effect related to the undissociated form of organic acids potentially produced by CM. Finally, the supernatant of the last tube was filtered through $0.2 \mu \mathrm{m}$ sterile Minisart syringe filters (Sartorius, Germany), resulting in a cell-free supernatant (CFS). The supernatants were inoculated in wells made in three PCA plates, previously spread with $100 \mu \mathrm{L}$ of each pathogenic bacterium (LM, EC, ST) at $6.0 \log \mathrm{CFU} /$ mL. Four treatments were applied on each plate: (1) sterile BHI broth (blank), (2) centrifuged supernatant, (3) centrifuged supernatant treated with $\mathrm{NaOH}$, and (4) centrifuged supernatant treated with $\mathrm{NaOH}$ and filtered (CFS). The halo of inhibition was measured after $48 \mathrm{~h}$ of incubation at $37{ }^{\circ} \mathrm{C}$, and all treatments were performed in triplicate.

\subsubsection{Minimum inhibitory concentration (MIC) of CM cell-free supernatant (CFS) towards $L M$}

CM_B824, CM_B827 and CM_B829 at $6.0 \log \mathrm{CFU} / \mathrm{mL}$ were incubated at two different growth conditions (at $25{ }^{\circ} \mathrm{C}$ for $48 \mathrm{~h}$ and $4{ }^{\circ} \mathrm{C}$ for 14 days) in co-culture with and without LM (3.0 log CFU/ mL). The combination of the different parameters resulted in 12 treatments: (1) CM_B824 at $25^{\circ} \mathrm{C}$ (2) CM_B824 + LM at $25^{\circ} \mathrm{C}$; (3) CM_B824 at $4{ }^{\circ} \mathrm{C}$, (4) CM_B824 + LM at $4{ }^{\circ} \mathrm{C}$, (5) CM_B827 at $25{ }^{\circ} \mathrm{C}$, (6) CM_B827 + LM at $25{ }^{\circ} \mathrm{C}$; (7) CM_B827 at $4{ }^{\circ} \mathrm{C}$, (8) CM_B827 + LM at $4{ }^{\circ} \mathrm{C}$, (9) CM_B829 at $25{ }^{\circ} \mathrm{C}$, (10) CM_B829 + LM at $25{ }^{\circ} \mathrm{C}$; (11) CM_B829 at $4{ }^{\circ} \mathrm{C}$, (12) CM_B829 + LM at $4{ }^{\circ} \mathrm{C}$.

After co-culture incubation, CFS of different treatments was obtained as described previously. CFS obtained from co-cultures and LM at $6.0 \log \mathrm{CFU} / \mathrm{mL}(10 \mu \mathrm{L})$, grown in BHI broth, were inoculated in 24well plates at different concentrations: $62.5,50,37.5$ and $18.75 \%$, that were composed by the combination $v / \mathrm{v}$ of CFS and sterile BHI broth. Plates were incubated at $37{ }^{\circ} \mathrm{C}$ for $24 \mathrm{~h}$ at $150 \mathrm{rpm}$, in triplicate. The growth of LM was verified visually. The minimum inhibitory concentration (MIC) was considered as the lowest concentration of the supernatant where no visible growth was observed (CLSI, 2012).

\subsection{Cooked ham essay}

The meat matrix essay was performed considering the results obtained in the in vitro essay. Therefore, the bioprotective effect of $\mathrm{CM}$ strains was assessed in a meat matrix stored at refrigeration against Listeria sp. A pool of L. innocua (LI) was used as surrogate for LM in this 
essay.

\subsubsection{Effect of CM against LI in sliced cooked ham}

Cooked ham was processed by a medium scale producer in Southern Brazil with pork ham muscles (M. semimembranosus, $M$. semitendinosus and $M$. biceps femoris) ( $4 \%$ fat). Muscles were injected with a brine solution (25 $\mathrm{g}$ brine/100 $\mathrm{g}$ ham meat), containing the following ingredients (g/ Kg): water, 100; salt, 20; sodium tri-polyphosphate, 3.0; sodium pyrophosphate 1.0; $\mathrm{NaNO}_{2}, 0.130 ; \mathrm{NaNO}_{3}, 0.260$; sodium erythorbate, 0.5; monosodium glutamate, 2; natural carmine dye, 0.3. After injection, meat was tumbled under vacuum at $4{ }^{\circ} \mathrm{C}$. After tumbling, the product was stuffed in multilayer shrinkable plastic casings (Schur, Barueri, São Paulo, Brazil) and placed in stainless steel molds (110 mm width, $120 \mathrm{~mm}$ height, $230 \mathrm{~mm}$ length). The product was then cooked in water bath at $85{ }^{\circ} \mathrm{C}$ until core temperature of $72{ }^{\circ} \mathrm{C}$ was reached. After cooking the product was pre-cooled in an ice bath until the core temperature was $50{ }^{\circ} \mathrm{C}$ and then cooled in a chilling room at $0{ }^{\circ} \mathrm{C}$ until reaching $4{ }^{\circ} \mathrm{C}$. After a minimum of $24 \mathrm{~h}$ of cooling, the mold was removed, and the product was sliced (dimensions $3 \mathrm{~mm} \times 105 \mathrm{~mm}$ width $\times 115 \mathrm{~mm}$ height) and packaged in expanded polystyrene trays and covered with low density polyvinyl chloride film.

Cooked ham slices from the same batch, with a shelf-life of 7 days, were purchased at the producer store. Slices were sterilized at $121{ }^{\circ} \mathrm{C}$ for 15 min (Alves, Martinez, Lavrador, \& De Martinis, 2006) to avoid the interference of the natural microbiota and chilled overnight at $4{ }^{\circ} \mathrm{C}$.

LI cold adaptation was performed as follows: strains were inoculated in BHI at $37{ }^{\circ} \mathrm{C}$ until stationary phase and subsequently cultured in BHI broth at $4{ }^{\circ} \mathrm{C}$ until stationary phase, which was confirmed by colony count in PCA agar plates. Equal volumes of each LI strain were mixed in a sterile flask to form a pool at the concentration of 3.0 $\log \mathrm{CFU} / \mathrm{mL}$. Then, three slices were distributed into eight treatments: (1) NC (negative control); (2) CM_B824; (3) CM_B827; (4) CM_B829; (5) LI; (6) CM_B824 + LI; (7) CM_B827 + LI; and (8) CM_B829 + LI.

Each side of ham slice was inoculated with $50 \mu \mathrm{L}$ of the LI pool at $3.0 \log \mathrm{CFU} / \mathrm{mL}$, which was spread evenly with a sterile Drigalski spatula. NC was inoculated with $50 \mu \mathrm{L} 0.1 \%$ peptone water. To allow the absorption of the inoculum, the slices were kept in a laminar flow cabinet for $1 \mathrm{~h}$ at room temperature. Then, the slices were inoculated with $50 \mu \mathrm{L}$ of each CM strain at $5.0 \log \mathrm{CFU} / \mathrm{mL}$, except treatment 5 (LI). After $1 \mathrm{~h}$, the slices were packed in sterile expanded polystyrene trays and covered with polyvinyl chloride film (permeability of $1400 \mathrm{~cm}^{3} \mathrm{O}_{2} / \mathrm{m}^{2} / 24 \mathrm{~h} / 22.8{ }^{\circ} \mathrm{C}$ ). The trays were stored in a low temperature incubator (Fanem $347 \mathrm{CD}$, São Paulo, Brazil) at $4{ }^{\circ} \mathrm{C}$ for 7 days. Samples were withdrawn at $0,2,5$ and 7 days of storage for the determination of $\mathrm{pH}$, instrumental color and bacterial counts.

\subsubsection{Determination of instrumental color}

The instrumental color was evaluated using a portable colorimeter (Model CR 410, Konica Minolta, Tokyo, Japan). The color was measured at three different points on the surface of ham slices. Measurement parameters were color space - CIE $L^{*} a^{*} b^{*}$, light source D65, opening diameter -50 to $53 \mathrm{~mm}$, and angle of observation $-2^{\circ}$. The hue value $[\mathrm{h}=\operatorname{ARCTAN}(\mathrm{b} / \mathrm{a})]$ and chroma $\left(\mathrm{C}^{*}=\sqrt{\mathrm{a}^{2}}+\mathrm{b}^{2}\right)$, which indicate intensity of discoloration and color saturation, respectively, were calculated.

\subsubsection{Determination of $\mathrm{pH}$}

For $\mathrm{pH}$ determination, $3 \mathrm{~g}$ of each sample were homogenized in $30 \mathrm{~mL}$ of deionized water for $1 \mathrm{~min}$ in a stomacher blender (Model Masticator Basic 2000, IUL, Barcelona, Spain). The $\mathrm{pH}$ value of the suspension was determined in triplicates using a pH-meter (Model HI 99163, Hanna, Póvoa de Varzim, Portugal) calibrated with buffer solutions at $\mathrm{pH} 4.0$ and 7.0.

\subsubsection{Microbiological analysis}

For microbiological analysis, the method adopted agreed with normative instruction number 62 from Ministry of Agriculture, Livestock and Food Supply (Brazil, 2003). $10 \mathrm{~g}$ of each sample were homogenized with $90 \mathrm{~mL}$ of sterilized peptone-water $(0.1 \% w / v)$ (Kasvi, São José dos Pinhais, Brazil) for 2 min using a stomacher blender (Masticator Basic 2000, IUL, Barcelona, Spain). Serial tenfold dilutions were performed, and $100 \mu \mathrm{L}$ of the selected dilution was inoculated on PCA for CM and PCA overlaid with $10 \mathrm{~mL}$ of melted PALCAM agar (Sigma Aldrich, MO, USA) for LI. CM population was estimated as the difference between counts on PCA and PCA overlaid with PALCAM agar. Moreover, the colonies of CM and LI were differentially counted in PCA agar based on colony size (colonies of CM being smaller). The experiment was carried out in duplicate. The plates were incubated at $37{ }^{\circ} \mathrm{C}$ for $48 \mathrm{~h}(\mathrm{LI})$ and at $25{ }^{\circ} \mathrm{C}$ for $48 \mathrm{~h}(\mathrm{CM})$.

\subsection{Statistical analysis}

The in vitro effect of $\mathrm{CM}$ on the growth of EC, LM and ST at different temperatures $\left(-1{ }^{\circ} \mathrm{C}, 4{ }^{\circ} \mathrm{C}\right.$ and $\left.25^{\circ} \mathrm{C}\right)$ and with the adittion of EDTA at $25{ }^{\circ} \mathrm{C}$ was analyzed by one-way ANOVA and means were compared by Tukey test $(P<.05)$, using VassarStats online.

Microbiological and physicochemical data obtained from cooked ham essay were analyzed using a random block design, considering a mixed linear model including treatment and storage time as fixed effects and replication as a random effect. Means were compared by Tukey test $(P<.05)$. Cooked ham assay was performed two times independently and differences between replicates were not significant $(P<.05)$. The microbiological analyses were conducted in duplicate $(n=4)$ and physicochemical analyses in triplicate $(n=6)$. For statistical analysis, bacterial counts with values below the limit of detection were considered as $0.69 \mathrm{log} \mathrm{CFU} / \mathrm{g}$. The analysis was performed using the software Statgraphics ${ }^{\circledR}$ Centurion XVI version 16.1.11 (Statpoint Technologies, Warrenton, Virginia, USA).

\section{Results and discussion}

\subsection{In vitro essay}

\subsubsection{Antimicrobial effect in co-culture}

LAB can inhibit spoilage and pathogenic microorganisms by competitive growth and synthesis of antagonistic compounds such as organic acids and bacteriocins (Gómez-Sala et al., 2016). When in coculture at $-1{ }^{\circ} \mathrm{C}, \mathrm{CM}$ strains were able to reduce the population of LM from 6.6 (control) to $<1.0$ (CM_B824), 2.3 (CM_B827), and 1.7 (CM_B829) $\log$ CFU/ mL (Fig. 1). However, EC and ST were not inhibited when co-cultured at $-1{ }^{\circ} \mathrm{C}$ with any of the $\mathrm{CM}$ strains (data not shown). Moreover, at $4{ }^{\circ} \mathrm{C}$, all CM isolates inhibited the growth of LM $(P<.05)$, showing a count reduction of a least $5.5 \log \mathrm{CFU} / \mathrm{mL}$ as compared to LM alone (negative control) (Fig. 2). Still, EC and ST were not inhibited at the condition of $4{ }^{\circ} \mathrm{C}$. The ability of $\mathrm{CM}$, differently from others LAB, to grow under low temperatures (Leisner et al., 2007) allows a competition with other bacteria in this kind of environment.

At $25{ }^{\circ} \mathrm{C}$, CM_B824 and CM_B827 showed a weak but significant inhibition effect towards LM $(P<.05)$ when in co-cultures (Fig. $3 \mathrm{E}$ ). $\mathrm{CM}$ did not show any inhibitory effect when grown in co-culture with EC and ST at $25^{\circ} \mathrm{C}$ (Fig. $3 \mathrm{~A}$ and 3C). However, when EDTA was added in the co-culture broth, all CM isolates reduced the growth of EC $(P<.05)$ (Fig. 3 B), and CM_B824 and CM_B827 inhibited the growth of ST and LM $(P<.05)$ (Fig. $3 \mathrm{D}$ and $3 \mathrm{~F})$.

As Carnobacterium is phylogenetically related to other genera of LAB it is possible to compare these bacteria (Hammes \& Hertel, 2006). Other authors also demonstrated the antilisterial activity of LAB. Rivas et al. (2014) showed the antilisterial activity of Lactobacillus curvatus and its purified bacteriocin, sakacin Q on cooked meat. Ho et al. (2018) found antilisterial activity in co-cultures of Lactococcus lactis, Lact. raffinolactis, Leuconostoc mesenteroides, Leuc. pseudomesenteroides, Weissella soli, and W. viridescens. Furthermore, Huang et al. (2016) demonstrated 


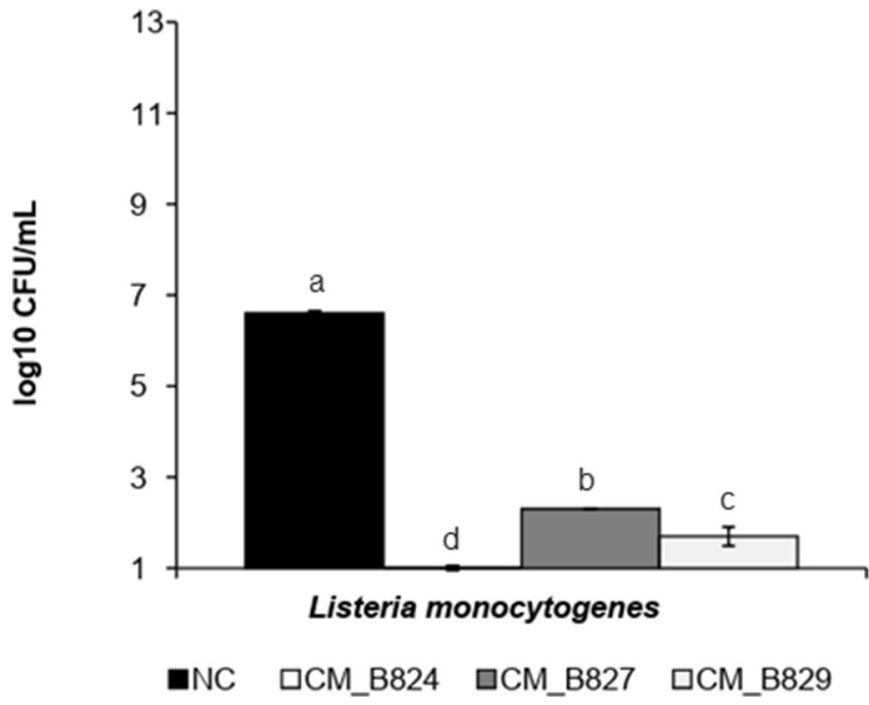

Fig. 1. Count of L. monocytogenes at co-culture with C. maltaromaticum isolates at $-1{ }^{\circ} \mathrm{C}$ for $28 \mathrm{~d}$.

$\mathrm{NC}=$ negative control; $\mathrm{CM}=$ Carnobacterium maltaromaticum.

No common superscript indicates that there is a significant difference among treatments $(P<.05)$.

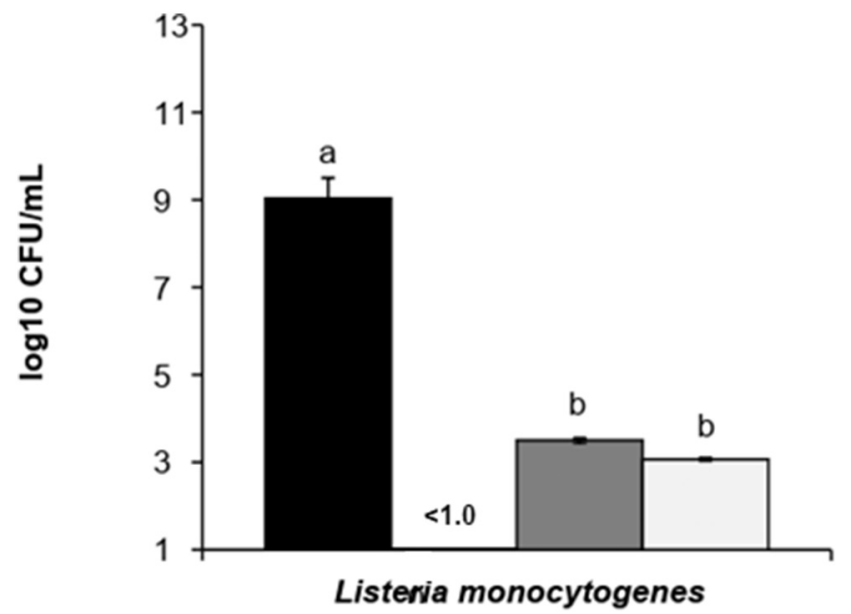

-NC 口CM_B824 口CM_B827 口CM_B829

Fig. 2. Count of $L$. monocytogenes at co-culture with $C$. maltaromaticum isolates at $4{ }^{\circ} \mathrm{C}$ for $14 \mathrm{~d}$.

$\mathrm{NC}=$ negative control; $\mathrm{CM}=$ Carnobacterium maltaromaticum .

No common superscript indicates that there is a significant difference among treatments $(P<.05)$.

the inhibition of LM when in co-culture with Enterococcus faecium B1/ B2.

Regarding the genus Carnobacterium, Alves et al. (2005) reported the antilisterial activity of a strain of CM (formerly Carnobacterium piscicola) isolated from Brazilian smoked fish. Dos Reis et al. (2011) also observed the antilisterial activity of CM in fish models. Moreover, Hammi et al. (2016) demonstrated an anti-Listeria activity by a new class IIa bacteriocin, termed maltaricin CPN, produced by a CM strain isolated from mold-ripened cheese.

Other authors observed inhibition of Gram-negative pathogens when bacteriocins from Gram-positive bacteria were analyzed in the presence of EDTA (Camargo, de Paula, Todorov, \& Nero, 2016; Field et al., 2017; O'Connor, Ross, Hill, \& Cotter, 2015; Prudêncio, Vanetti, \& Prieto, 2015). A bacteriocin produced by CM UAL307, termed carnocyclin A, showed an antimicrobial activity against Gram-negative bacteria including EC and Pseudomonas aeruginosa, when incubated with EDTA (Martin-Visscher, Yoganathan, Sit, Lohans, \& Vederas, 2011). Bacterial metabolites can become more effective biopreservatives when used in combination with other hurdles such as chelating agents. This combination is a strategy to increase the activity of the bacteriocins produced by Gram-positive bacteria. As the composition of membranes from Gram-positive bacteria and Gram-negative bacteria are different, multiple approaches for increasing the activity of a bacteriocin or other bacterial metabolites are necessary (Hwanhlem, Ivanova, Haertlé, Jaffrès, \& Dousset, 2017). The chelating capacity of EDTA, which acts by removing $\mathrm{Mg} 2+$ and $\mathrm{Ca} 2+$, promotes the destabilization of the outer membrane from Gram-negative bacteria, allowing metabolites to access the cytoplasmic membrane (Field et al., 2017; Mathur et al., 2017).

\subsection{Antimicrobial effect of CFS}

Regarding the CFS essays, there was no inhibition effect on LM, EC and ST growth in agar well diffusion at the tested conditions. In the MIC determination, there was no inhibition of LM using the different CFS treatments and concentrations. Similarly, Schillinger and Holzapfel (1990) did not observe any antilisterial effect of CFS obtained from 37 isolates of Carnobacterium spp. Arena et al. (2016) also did not find any inhibitory effect of CFS obtained from 79 Lactobacillus plantarum isolates towards LM, EC, Salmonella sp. and Staphylococcus aureus using CFS in a well-diffusion assay. However, when these pathogens were challenged in the presence of the cells of L. plantarum an inhibitory effect was observed for 17 strains.

Based on these results, the isolates of CM used in this study are not likely to produce bacteriocins under the studied conditions. The bacteriocin production is related to the maximum cell growth and shows primary metabolic kinetics. So, the metabolization of bacteriocins are strictly related to optimal conditions of growth for the bacteriocinogenic strain, which depends on environmental conditions such as $\mathrm{pH}$, temperature, media composition, aeration, salinity, agitation and incubation atmosphere (Elayaraja, Annamalai, Mayavu, \& Balasubramanian, 2014; Malheiros, Sant'Anna, Todorov, \& Franco, 2015; Yang et al., 2018). For C. maltaromaticum, the best temperatures to maximum production of bacteriocin were found to be around $19{ }^{\circ} \mathrm{C}$ (Gursky et al., 2006).

Thus, the LM inhibition observed at the co-culture essays may be explained by the production of organic acids or other antibacterial metabolites, the competition of nutrients, the need of a more direct interaction between bacteria to activate the antimicrobial mechanisms or even, by the production of bacteriocins, although this production was not enough to cause a significant inhibition (Arena et al., 2016; Chanos \& Mygind, 2016; Yang et al., 2018).

Each isolate of each species appears to have an exclusive optimal condition to produce bacteriocins, and these conditions should be determined for each parameter and producer isolate (Masuda, Perez, Zendo, \& Sonomoto, 2016; Pérez, González, Agrasar, \& Guerra, 2013; Sidooski, Brandelli, Bertoli, Souza, \& Carvalho, 2018).

\subsection{Cooked ham essay}

\subsubsection{Microbiological analysis}

The use of $\mathrm{LAB}$ as protective cultures to improve safety and prolong the shelf life of the meat products, including cooked meat products, is a concept that has been suggested by many authors (Comi, Andyanto, Manzano, \& Iacumin, 2016; Metaxopoulos, Mataragas, \& Drosinos, 2002; Vermeiren, Devlieghere, \& Debevere, 2004).

There was significant interaction between 'treatment' and 'storage time' for the count of CM in cooked ham $(P<.05)$ (Table 3). For LI count, there was no interaction between the fixed effects, but there was independent effect of 'treatment' and 'storage time' $(P<.05)$.

During storage, the count of CM varied significantly, however, 

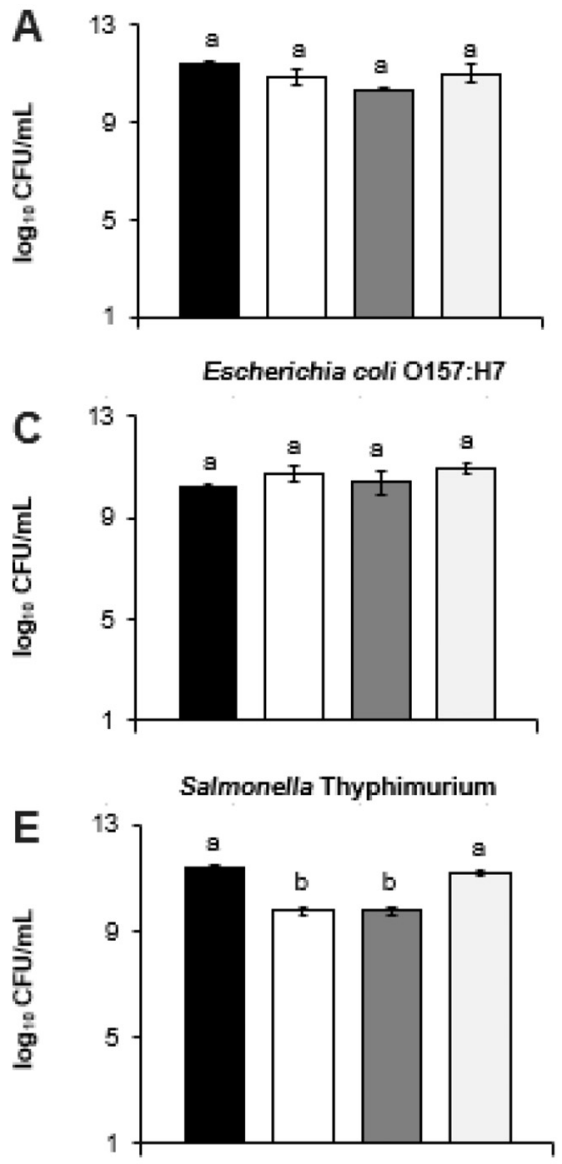

Listeria monocytogenes WITHOUT EDTA

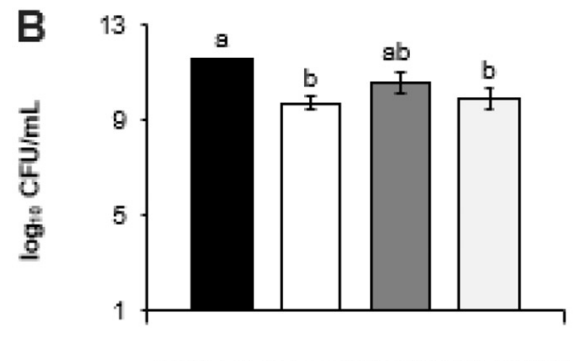

Escherichia coli O157:H7 (+ EDTA)
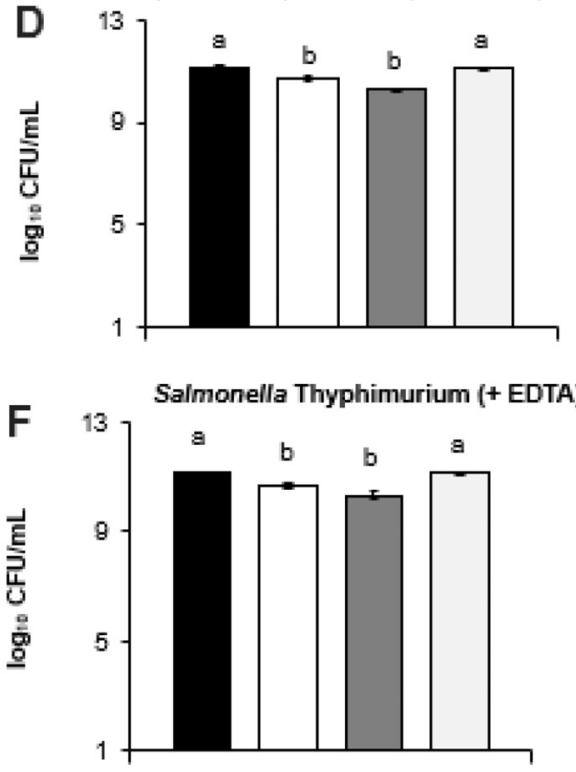

Listeria monocytogenes (+ EDTA)

WITH EDTA

-NC 口CM_B824 口CM_B827 口CM_B829

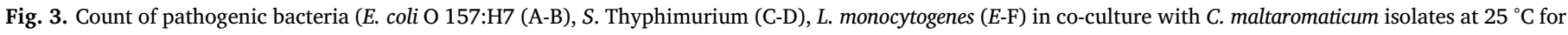
$48 \mathrm{~h}$, with and without EDTA.

$\mathrm{NC}=$ negative control; $\mathrm{CM}=$ Carnobacterium maltaromaticum.

count differences were $<0.4 \log \mathrm{CFU} / \mathrm{g}$ in all CM-treatments from day 1 to day 7 of storage, showing adaptation of CM strains to the cured cooked meat matrix. Conversely, the count of LI in the CM + LI treatments reduced significantly during storage, whereas the count of LI in the LI-treatment did not differ during storage $(P>.05)$. At 2 days of storage, the count of LI in the CM + LI treatments decreased to nondetected level $(<0.69 \log \mathrm{CFU} / \mathrm{g})$ and the addition of CM_B829 reduced the count of LI $>2.0 \mathrm{log} \mathrm{CFU} / \mathrm{g}$ after 7 days of storage. CM_B824 and CM_B827 also caused a significant reduction of LI in ham during storage $(P<.05)$. This inhibition of L. innocua may be attributed to the greater ability of Carnobacterium to grow and to adapt to this food matrix and storage conditions in comparison to Listeria (Amézquita; Brashears, 2002). This ability leads to a depletion of nutrients hindering the growth of the pathogen, as well as the occupation of the food matrix before the pathogen (Nilsson et al., 2005; Vermeiren et al., 2004).

Although the ability of Carnobacterium strains to produce bacteriocins under the studied conditions has not been proven, the bacteriocin production by LAB does not always lead to increased inhibitory activity towards pathogenic bacteria. Vermeinen et al. (2004) studied the antilisterial activity of LAB, able or not to produce bacteriocins, in cooked ham stored at 4 and $7{ }^{\circ} \mathrm{C}$ and observed that strains that did not produce bacteriocin had a greater inhibition of the growth of Listeria sp. The occurrence of resistant L. monocytogenes target organisms has led to the suggestion that bacteriocin-negative LAB may be more suitable for practical use as bioprotective agents against L. monocytogenes in readyto-eat foods (Nilsson et al., 2005; Vermeiren et al., 2004). Indeed, $L$. monocytogenes is inhibited by carnobacteria that do not produce bacteriocins, and this is partly due to glucose depletion (Leisner et al., 2007).

\subsubsection{Color and $p H$}

There were significant interactions between 'treatment' and 'storage time' for $\mathrm{pH}$ and instrumental color coordinates of cooked ham $(P<.05)$ (Tables 1 and 2 ). A slight increase in luminosity ( $\left.L^{*}\right)$ and a slight decrease in $\mathrm{pH}$ was observed in ham from all treatments during storage. The addition of CM strains in cooked ham did not cause significant changes in the $\mathrm{pH}$ of the product, which remained similar to NC and LI during storage. After 7 days of storage, CM_824 + LI showed lower $\mathrm{pH}$ than other treatments $(P<.05)$, however, the $\mathrm{pH}$ values in all treatments were within the normal range for this type of meat product, i.e., 5.6-6.2 (Arnau, Guerrero, Casademont, \& Gou, 1995). Gao, Li, and Liu (2015) found that the addition of L. sakei C2 in vacuum packed sliced cooked ham decreased the $\mathrm{pH}$ value during the storage at refrigerated temperature. Conversely to other aciduric LAB genera such as Lactobacillus, Leuconostoc and Pediococcus, Carnobacterium is not a strong acid producer. Even if carbohydrate catabolism by carnobacteria appears to result in a diverse number of metabolites, these have 
Table 1

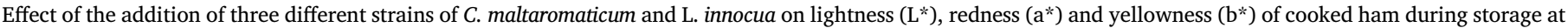
$4{ }^{\circ} \mathrm{C}$ for 7 days.

\begin{tabular}{|c|c|c|c|c|c|}
\hline \multirow[t]{2}{*}{ Treament } & \multicolumn{5}{|l|}{ Storage days } \\
\hline & 0 & 2 & 5 & 7 & $P$ value \\
\hline & $\mathrm{L}^{*}$ & & & & \\
\hline $\mathrm{NC}$ & $60.10 \pm 0.66^{\mathrm{abB}}$ & $63.05 \pm 0.27^{\mathrm{abA}}$ & $63.26 \pm 0.57^{\mathrm{aA}}$ & $62.91 \pm 0.62^{\mathrm{aA}}$ & 0.0017 \\
\hline $\mathrm{LI}$ & $60.28 \pm 0.71^{\mathrm{abB}}$ & $63.65 \pm 0.39^{\mathrm{aA}}$ & $64.20 \pm 0.24^{\mathrm{aA}}$ & $65.35 \pm 0.94^{\mathrm{aA}}$ & 0.0001 \\
\hline CM_824 & $59.90 \pm 0.66^{\mathrm{abB}}$ & $63.56 \pm 0.23^{\mathrm{aA}}$ & $63.83 \pm 0.34^{\mathrm{aA}}$ & $64.55 \pm 0.36^{\mathrm{aA}}$ & 0.0000 \\
\hline CM_827 & $61.04 \pm 0.41^{\mathrm{abC}}$ & $62.60 \pm 0.48^{\mathrm{abBC}}$ & $63.52 \pm 0.58^{\mathrm{aAB}}$ & $64.70 \pm 0.59^{\mathrm{aA}}$ & 0.0006 \\
\hline CM_829 & $59.18 \pm 0.85^{\mathrm{bB}}$ & $62.07 \pm 0.47^{\mathrm{abA}}$ & $62.83 \pm 0.40^{\mathrm{aA}}$ & $64.13 \pm 0.28^{\mathrm{aA}}$ & 0.0000 \\
\hline CM_824 + LI & $61.23 \pm 0.70^{\mathrm{abA}}$ & $60.92 \pm 0.59^{\mathrm{bcA}}$ & $63.10 \pm 0.48^{\mathrm{aA}}$ & $62.97 \pm 0.81^{\mathrm{aA}}$ & 0.0538 \\
\hline CM_827 + LI & $61.99 \pm 0.54^{\mathrm{abA}}$ & $59.71 \pm 0.44^{\mathrm{cA}}$ & $61.03 \pm 1.92^{\mathrm{aA}}$ & $63.17 \pm 0.29^{\mathrm{aA}}$ & 0.1430 \\
\hline CM_829 + LI & $62.32 \pm 0.61^{\mathrm{aA}}$ & $63.11 \pm 0.71^{\mathrm{aA}}$ & $61.20 \pm 0.96^{\mathrm{aA}}$ & $63.98 \pm 0.44^{\mathrm{aA}}$ & 0.4327 \\
\hline \multirow[t]{2}{*}{$P$ value } & 0.0208 & 0.0000 & 0.1007 & 0.0454 & \\
\hline & $a^{*}$ & & & & \\
\hline $\mathrm{NC}$ & $17.13 \pm 1.01^{\mathrm{abA}}$ & $15.51 \pm 0.32^{\mathrm{aA}}$ & $17.33 \pm 0.32^{\mathrm{aA}}$ & $16.38 \pm 0.56^{\mathrm{aA}}$ & 0.1822 \\
\hline LI & $17.32 \pm 0.64^{\mathrm{abA}}$ & $16.10 \pm 0.54^{\mathrm{aA}}$ & $17.40 \pm 0.30^{\mathrm{aA}}$ & $16.37 \pm 0.56^{\mathrm{aA}}$ & 0.2248 \\
\hline CM_824 & $16.84 \pm 0.57^{\mathrm{abA}}$ & $16.44 \pm 0.42^{\mathrm{aA}}$ & $17.53 \pm 0.42^{\mathrm{aA}}$ & $15.73 \pm 0.88^{\mathrm{aA}}$ & 0.2321 \\
\hline CM_827 & $17.63 \pm 0.57^{\mathrm{aA}}$ & $15.34 \pm 0.15^{\mathrm{abB}}$ & $16.94 \pm 0.26^{\mathrm{abA}}$ & $14.59 \pm 0.27^{\mathrm{aB}}$ & 0.0000 \\
\hline CM_829 & $16.09 \pm 0.62^{\mathrm{abAB}}$ & $16.73 \pm 0.44^{\mathrm{aAB}}$ & $17.71 \pm 0.43^{\mathrm{aA}}$ & $15.88 \pm 0.18^{\mathrm{aB}}$ & 0.0374 \\
\hline CM_824 + LI & $15.17 \pm 0.21^{\mathrm{abA}}$ & $13.25 \pm 0.70^{\mathrm{bB}}$ & $16.15 \pm 0.50^{\mathrm{abA}}$ & $16.43 \pm 0.37^{\mathrm{aA}}$ & 0.0005 \\
\hline CM_827 + LI & $14.81 \pm 0.59^{\mathrm{bBC}}$ & $13.27 \pm 0.62^{\mathrm{bC}}$ & $16.79 \pm 0.25^{\mathrm{abA}}$ & $15.96 \pm 0.26^{\mathrm{aAB}}$ & 0.0002 \\
\hline CM_829 + LI & $15.73 \pm 0.63^{\mathrm{abA}}$ & $15.58 \pm 0.53^{\mathrm{aA}}$ & $15.54 \pm 0.45^{\mathrm{bA}}$ & $14.67 \pm 0.31^{\mathrm{aA}}$ & 0.3356 \\
\hline \multirow[t]{2}{*}{$P$ value } & 0.0159 & 0.0000 & 0.0024 & 0.0349 & \\
\hline & $b^{*}$ & & & & \\
\hline $\mathrm{NC}$ & $12.31 \pm 0.60^{\mathrm{bcA}}$ & $11.25 \pm 0.40^{\mathrm{abA}}$ & $11.51 \pm 0.61^{\mathrm{aA}}$ & $11.64 \pm 0.34^{\mathrm{aA}}$ & 0.5059 \\
\hline LI & $13.55 \pm 0.65^{\mathrm{bcA}}$ & $11.50 \pm 0.48^{\mathrm{abA}}$ & $11.92 \pm 0.50^{\mathrm{aA}}$ & $12.73 \pm 0.58^{\mathrm{aA}}$ & 0.0750 \\
\hline CM_824 & $10.94 \pm 0.16^{\mathrm{cB}}$ & $11.75 \pm 0.07^{\mathrm{aAB}}$ & $11.99 \pm 0.62^{\mathrm{aAB}}$ & $12.71 \pm 0.36^{\mathrm{aA}}$ & 0.0246 \\
\hline CM_827 & $14.56 \pm 0.29^{\mathrm{abA}}$ & $11.33 \pm 0.45^{\mathrm{abB}}$ & $11.44 \pm 0.49^{\mathrm{aB}}$ & $12.04 \pm 0.35^{\mathrm{aB}}$ & 0.0000 \\
\hline CM_829 & $17.19 \pm 0.99^{\mathrm{aA}}$ & $11.59 \pm 0.66^{\mathrm{abB}}$ & $11.13 \pm 0.15^{\mathrm{aB}}$ & $12.30 \pm 0.25^{\mathrm{aB}}$ & 0.0000 \\
\hline CM_824 + LI & $11.52 \pm 0.46^{\mathrm{cAB}}$ & $10.50 \pm 0.33^{\mathrm{abB}}$ & $12.60 \pm 0.34^{\mathrm{aA}}$ & $12.40 \pm 0.44^{\mathrm{aA}}$ & 0.0048 \\
\hline CM_827 + LI & $11.76 \pm 0.75^{\mathrm{cA}}$ & $9.89 \pm 0.13^{\mathrm{bB}}$ & $12.37 \pm 0.31^{\mathrm{aA}}$ & $11.61 \pm 0.36^{\mathrm{aAB}}$ & 0.0052 \\
\hline CM_829 + LI & $11.75 \pm 0.44^{\mathrm{cA}}$ & $12.34 \pm 0.39^{\mathrm{aA}}$ & $11.60 \pm 0.49^{\mathrm{aA}}$ & $12.30 \pm 0.20^{\mathrm{aA}}$ & 0.5228 \\
\hline$P$ value & 0.0000 & 0.0071 & 0.3624 & 0.2701 & \\
\hline
\end{tabular}

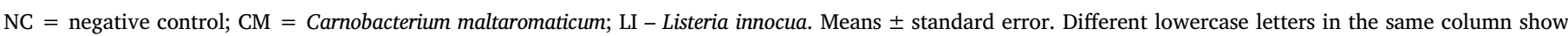
significant differences among treatments $(P<.05)$. Different uppercase letters in the same row show significant differences among storage time $(P<.05)$.

generally a limited effect on the sensory attributes of foods (Leisner et al., 2007).

Regarding color parameters, there were small, but significant differences in instrumental color values between treatments during storage. However, those differences are likely due to intrinsic characteristics of the product itself than to the influence of the treatments.

The acceptability of cooked ham by the consumers is strongly related to the color of the product (Lloret, Picouet, Trbojevich, \& Fernández, 2016). Changes in the color of a meat product caused by Carnobacterium was reported only by Peirson, Guan, and Holley (2003) who observed that a strain of $C$. viridans induced greening in cured bologna. However, this effect was detected only after the opening of the vacuum packages and took 2 days or less at $9{ }^{\circ} \mathrm{C}$ and 3 days at $4{ }^{\circ} \mathrm{C}$. Nonetheless, the authors state that representative strains of most known species of Carnobacterium failed to cause discoloration in this type of cooked meat product.

As Carnobacterium are frequently predominant members of the $\mathrm{LAB}$ microbiota of non-spoiled raw meat and processed meat products, including ham and bacon, irrespective of whether products have been stored aerobically, vacuum packaged, or subjected to modified atmospheres, they normally do not cause changes in the physicochemical and sensory characteristics of the product (Li et al., 2018). Additionally, high concentrations of bacteria $\left(>10^{6}-10^{7} \mathrm{CFU} / \mathrm{g}\right)$ in food are typically required before their activity is enough to influence the sensory properties of a product (Leisner et al., 2007). Gao et al. (2015) and Comi et al. (2016) reported that Lactobacillus sakei and Lactococcus lactis affected the growth of spoilage bacteria and L. monocytogenes and did not negatively affect the physicochemical properties of sliced cooked ham and cooked bacon, respectively. On the other hand, the addition of C. maltaromaticum in meat products as a protective culture has not been assessed. Thus, it could be considered that the addition of the CM strains in the present study did not negatively affect the physicochemical parameters of the product.

The C. maltaromaticum isolates used in this study present several properties that are desirable for biopreservative cultures: the isolates were able to growth and the count remained stable in the cooked ham during storage, the isolates did not cause significant changes in $\mathrm{pH}$ and color of the product and the fast inhibition of L. innocua, at the second day of storage, is another advantage of these isolates.

As the artificial contamination of ham in this study extrapolated the natural contamination observed in the food industry by Listeria sp., the C. maltaromaticum could show more successful antimicrobial results in practical conditions. Despite the promising results observed in the present study, the possible impact of the addition of the Carnobacterium isolates as protective culture on sensory properties of the meat product should be further investigated.

\section{Conclusion}

The three $C$. maltaromaticum strains tested showed an antilisterial potential in vitro, which was more important at $-1{ }^{\circ} \mathrm{C}$ and $4{ }^{\circ} \mathrm{C}$ than at $25{ }^{\circ} \mathrm{C}$. When applied in cooked ham, the antilisterial potential was confirmed, since the growth of Listeria spp. was inhibited by the addition of the strains of $C$. maltaromaticum, without affecting the physicochemical quality of the product. Therefore, $C$. maltaromaticum strains show potential to be used as bioprotective culture in cooked meat product to improve its safety. 
Table 2

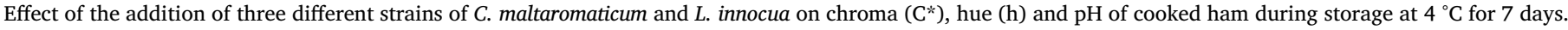

\begin{tabular}{|c|c|c|c|c|c|}
\hline \multirow[t]{2}{*}{ Treatment } & \multicolumn{5}{|l|}{ Storage days } \\
\hline & 0 & 2 & 5 & 7 & $P$ value \\
\hline & $C^{*}$ & & & & \\
\hline $\mathrm{NC}$ & $21.15 \pm 1.10^{\mathrm{bcdA}}$ & $19.18 \pm 0.20^{\mathrm{abA}}$ & $20.85 \pm 0.26^{\mathrm{aA}}$ & $20.17 \pm 0.33^{\mathrm{abA}}$ & 0.1266 \\
\hline LI & $22.02 \pm 0.71^{\mathrm{abcA}}$ & $19.80 \pm 0.51^{\mathrm{aB}}$ & $21.12 \pm 0.36^{\mathrm{aAB}}$ & $19.80 \pm 0.25^{\mathrm{abB}}$ & 0.0100 \\
\hline CM_824 & $20.08 \pm 0.52^{\mathrm{cdA}}$ & $20.22 \pm 0.34^{\mathrm{aA}}$ & $21.25 \pm 0.65^{\mathrm{aA}}$ & $19.70 \pm 0.35^{\mathrm{abA}}$ & 0.1630 \\
\hline CM_827 & $23.23 \pm 0.50^{\mathrm{abA}}$ & $19.09 \pm 0.31^{\mathrm{abB}}$ & $20.43 \pm 0.47^{\mathrm{aB}}$ & $18.92 \pm 0.29^{\mathrm{bB}}$ & 0.0000 \\
\hline CM_829 & $24.61 \pm 0.71^{\mathrm{aA}}$ & $20.37 \pm 0.71^{\mathrm{aB}}$ & $20.93 \pm 0.34^{\mathrm{aB}}$ & $20.09 \pm 0.15^{\mathrm{abB}}$ & 0.0000 \\
\hline CM_824 + LI & $18.76 \pm 0.47^{\mathrm{dAB}}$ & $16.92 \pm 0.69^{\mathrm{bcB}}$ & $20.51 \pm 0.36^{\mathrm{aA}}$ & $20.44 \pm 0.58 \mathrm{~B}^{\mathrm{aA}}$ & 0.0003 \\
\hline CM_827 + LI & $18.45 \pm 0.26^{\mathrm{dB}}$ & $16.58 \pm 0.45^{\mathrm{cC}}$ & $20.87 \pm .026^{\mathrm{aA}}$ & $19.76 \pm 0.18^{\mathrm{abA}}$ & 0.0000 \\
\hline CM_829 + LI & $19.63 \pm 0.56^{\mathrm{cdA}}$ & $19.82 \pm 0.57^{\mathrm{aA}}$ & $20.00 \pm .36^{\mathrm{aA}}$ & $19.15 \pm 0.29^{\mathrm{abA}}$ & 0.6064 \\
\hline \multirow[t]{2}{*}{$P$ value } & 0.0000 & 0.0000 & 0.4157 & 0.0335 & \\
\hline & $\mathrm{h}$ & & & & \\
\hline $\mathrm{NC}$ & $35.77 \pm 1.11^{\mathrm{bcA}}$ & $35.96 \pm 1.42^{\mathrm{aA}}$ & $33.55 \pm 1.76^{\mathrm{abA}}$ & $35.01 \pm 1.60^{\mathrm{aA}}$ & 0.6609 \\
\hline LI & $38.02 \pm 1.45^{\mathrm{bcA}}$ & $35.55 \pm 1.50^{\mathrm{aA}}$ & $34.37 \pm 1.25^{\mathrm{abA}}$ & $40.13 \pm 1.90^{\mathrm{aA}}$ & 0.0675 \\
\hline CM_824 & $33.02 \pm 0.85^{\mathrm{cB}}$ & $35.60 \pm 0.74^{\mathrm{aAB}}$ & $33.75 \pm 1.14^{\mathrm{abB}}$ & $40.11 \pm 2.09^{\mathrm{aA}}$ & 0.0048 \\
\hline CM_827 & $40.50 \pm 1.59^{\mathrm{abA}}$ & $36.39 \pm 1.09^{\mathrm{aAB}}$ & $33.86 \pm 0.88^{\mathrm{abB}}$ & $39.60 \pm 1.07^{\mathrm{aA}}$ & 0.0028 \\
\hline CM_829 & $46.01 \pm 1.33^{\mathrm{aA}}$ & $34.58 \pm 1.06^{\mathrm{aBC}}$ & $32.20 \pm 0.81^{\mathrm{bC}}$ & $37.77 \pm 0.77^{\mathrm{aB}}$ & 0.0000 \\
\hline CM_824 + LI & $37.05 \pm 0.92^{\mathrm{bcA}}$ & $38.56 \pm 1.16^{\mathrm{aA}}$ & $38.02 \pm 1.37^{\mathrm{aA}}$ & $37.00 \pm 0.69^{\mathrm{aA}}$ & 0.6754 \\
\hline CM_827 + LI & $37.18 \pm 2.07^{\mathrm{bcA}}$ & $36.88 \pm 1.55^{\mathrm{aA}}$ & $36.35 \pm 0.85^{\mathrm{abA}}$ & $36.04 \pm 1.11^{\mathrm{aA}}$ & 0.9463 \\
\hline CM_829 + LI & $36.74 \pm 0.74^{\mathrm{bcA}}$ & $38.22 \pm 0.94^{\mathrm{aA}}$ & $37.54 \pm 1.64^{\mathrm{abA}}$ & $39.99 \pm 0.70^{\mathrm{aA}}$ & 0.2078 \\
\hline \multirow[t]{2}{*}{$P$ value } & 0.0000 & 0.2915 & 0,0191 & 0.0461 & \\
\hline & $\mathrm{pH}$ & & & & \\
\hline $\mathrm{NC}$ & $6.42 \pm 0.02^{\mathrm{aA}}$ & $5.92 \pm 0.02^{\mathrm{aB}}$ & $5.70 \pm 0.02^{\mathrm{bC}}$ & $5.88 \pm 0.02^{\mathrm{aB}}$ & 0.0000 \\
\hline LI & $6.33 \pm 0.11^{\mathrm{aA}}$ & $5.61 \pm 0.01^{\mathrm{cC}}$ & $5.72 \pm 0.05^{\mathrm{bBC}}$ & $5.87 \pm 0.02^{\mathrm{aB}}$ & 0.0000 \\
\hline CM_824 & $5.93 \pm 0.01^{\mathrm{bA}}$ & $5.64 \pm 0.02^{\mathrm{cB}}$ & $5.61 \pm 0.02^{\mathrm{bB}}$ & $5.87 \pm 0.02^{\mathrm{aA}}$ & 0.0000 \\
\hline CM_827 & $6.46 \pm 0.02^{\mathrm{aA}}$ & $5.85 \pm 0.04^{\mathrm{abB}}$ & $5.61 \pm 0.01^{\mathrm{bC}}$ & $5.89 \pm 0.03^{\mathrm{aB}}$ & 0.0000 \\
\hline CM_829 & $6.47 \pm 0.02^{\mathrm{aA}}$ & $5.94 \pm 0.03^{\mathrm{aB}}$ & $5.62 \pm 0.01^{\mathrm{bC}}$ & $5.93 \pm 0.03^{\mathrm{aB}}$ & 0.0000 \\
\hline CM_824 + LI & $5.83 \pm 0.01^{\mathrm{bB}}$ & $5.93 \pm 0.02^{\mathrm{aA}}$ & $5.89 \pm 0.02^{\mathrm{aAB}}$ & $5.66 \pm 0.02^{\mathrm{bC}}$ & 0.0000 \\
\hline CM_827 + LI & $5.82 \pm 0.01^{\mathrm{bAB}}$ & $5.94 \pm 0.01^{\mathrm{aA}}$ & $5.90 \pm 0.02^{\mathrm{aAB}}$ & $5.80 \pm 0.06^{\mathrm{aB}}$ & 0.0196 \\
\hline CM_829 + LI & $5.85 \pm 0.03^{\mathrm{bA}}$ & $5.76 \pm 0.07^{\mathrm{bcA}}$ & $5.90 \pm 0.02^{\mathrm{aA}}$ & $5.91 \pm 0.02^{\mathrm{aA}}$ & 0.0649 \\
\hline$P$ & 0.0000 & 0.0000 & 0.0000 & 0.0000 & \\
\hline
\end{tabular}

$\mathrm{NC}=$ negative control; $\mathrm{CM}=$ Carnobacterium maltaromaticum; LI - Listeria innocua. Means \pm standard error. Different lowercase letters in the same column show significant differences among treatments $(P<.05)$. Different uppercase letters in the same row show significant differences among storage time $(P<.05)$.

Table 3

Count of the different strains of $C$. maltaromaticum and the pool of L. innocua in sliced cooked ham stored at $4{ }^{\circ} \mathrm{C}$ for 7 days.

\begin{tabular}{|c|c|c|c|c|c|}
\hline \multirow[t]{2}{*}{ Treatment } & \multicolumn{5}{|l|}{ Storage days } \\
\hline & 0 & 2 & 5 & 7 & $P$ \\
\hline & \multicolumn{5}{|c|}{ Count of $C$. maltaromaticum (log CFU/g) } \\
\hline CM_B824 & $5.60 \pm 0.02^{\mathrm{aA}}$ & $5.60 \pm 0.02^{\mathrm{aAB}}$ & $5.26 \pm 0.02^{\mathrm{abC}}$ & $5.33 \pm 0.03^{\mathrm{aBC}}$ & 0.0120 \\
\hline CM_B827 & $5.42 \pm 0.07^{\mathrm{aA}}$ & $5.41 \pm 0.07^{\mathrm{aA}}$ & $5.08 \pm 0.03^{\mathrm{bA}}$ & $5.40 \pm 0.05^{\mathrm{aA}}$ & 0.0034 \\
\hline CM_B829 & $5.49 \pm 0.05^{\mathrm{aA}}$ & $5.48 \pm 0.05^{\mathrm{aA}}$ & $5.34 \pm 0.08^{\mathrm{aA}}$ & $5.35 \pm 0.03^{\mathrm{aA}}$ & 0.2163 \\
\hline CM_B824 + LI & $4.75 \pm 0.00^{\mathrm{bA}}$ & $4.75 \pm 0.00^{\mathrm{bA}}$ & $4.64 \pm 0.01^{\mathrm{cB}}$ & $4.31 \pm 0.01^{\mathrm{cC}}$ & 0.0000 \\
\hline CM_B827 + LI & $4.50 \pm 0.14^{\mathrm{bA}}$ & $4.49 \pm 0.13^{\mathrm{bA}}$ & $4.60 \pm 0.01^{\mathrm{cA}}$ & $4.34 \pm 0.02^{\mathrm{cA}}$ & 0.2174 \\
\hline CM_B829 + LI & $4.46 \pm 0.03^{\mathrm{bB}}$ & $4.46 \pm 0.03^{\mathrm{bB}}$ & $4.71 \pm 0.05^{\mathrm{cA}}$ & $4.54 \pm 0.03^{\mathrm{bAB}}$ & 0.0222 \\
\hline \multirow[t]{2}{*}{$P$} & 0.0000 & 0.0002 & 0.0056 & 0.0075 & \\
\hline & \multicolumn{5}{|c|}{ Count of L. innocua $(\log \mathrm{CFU} / \mathrm{g})$} \\
\hline LI & $3.06 \pm 0.02^{\mathrm{aA}}$ & $2.60 \pm 0.11^{\mathrm{aA}}$ & $2.59 \pm 0.50^{\mathrm{aA}}$ & $2.40 \pm 0.09^{\mathrm{aA}}$ & 0.1190 \\
\hline CM_B824 + LI & $2.15 \pm 0.15^{\mathrm{bB}}$ & $\mathrm{ND}^{\mathrm{bB}}$ & $\mathrm{ND}^{\mathrm{bB}}$ & $1.350 \pm 0.50^{\mathrm{bAB}}$ & 0.0355 \\
\hline CM_B827 + LI & $2.00 \pm 0.00^{\mathrm{bB}}$ & $\mathrm{ND}^{\mathrm{bB}}$ & $\mathrm{ND}^{\mathrm{bB}}$ & $\mathrm{ND}^{\mathrm{bB}}$ & 0.0298 \\
\hline CM_B829 + LI & $2.15 \pm 0.15^{\mathrm{bB}}$ & $\mathrm{ND}^{\mathrm{bB}}$ & $1.50 \pm 0.50^{\mathrm{bAB}}$ & $\mathrm{ND}^{\mathrm{bB}}$ & 0.0079 \\
\hline$P$ & 0.0067 & 0.0004 & 0.0042 & 0.0133 & \\
\hline
\end{tabular}

$\mathrm{CM}=$ Carnobacterium maltaromaticum; LI - Listeria innocua.

$\mathrm{ND}=$ non-detected (limit of detection $=0.69 \log \mathrm{CFU} / \mathrm{g}$ ).

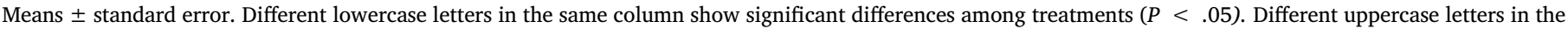
same row show significant differences among storage time $(P<.05)$.

\section{Declaration of Competing Interest}

The authors declare that there is no conflict of interest. This statement is to certify that all authors have seen and approved the manuscript being submitted.

We warrant that the article is the authors' original work. We warrant that the article is not under consideration for publication elsewhere.

On behalf of all co-authors, the corresponding author shall bear full responsibility for the submission.

We attest to the fact that all authors listed on the title page have contributed significantly to the work, have read the manuscript, attest to the validity and legitimacy of the data and its interpretation, and agree to its submission to Meat Science. 


\section{Acknowledgements}

This work was financed by the Pontifical Catholic University of Paraná and the University of Liège ("Fonds Spéciaux de la Recherche FMV - 2017"). The authors are grateful to the funding and all the technical support provided.

\section{References}

Alves, V., Martinis, E., Destro, M., Vogel, B., \& Gram, L. (2005). Antilisterial activity of a Carnobacterium piscicola isolated from Brazilian smoked fish (surubim [Pseudoplatystoma sp.]) and its activity against a persistent strain of Listeria monocytogenes isolated from surubim. Journal of Food Protection, 68(10), 2068-2077.

Alves, V. F., Martinez, R. C. R., Lavrador, M. A. S., \& De Martinis, E. C. P. (2006). Antilisterial activity of lactic acid bacteria inoculated on cooked ham. Meat Science, 74(4), 623-627.

Arena, M. P., Silvain, A., Normanno, G., Grieco, F., Drider, D., Spano, G., \& Fiocco, D. (2016). Use of Lactobacillus plantarum strains as a bio-control strategy against foodborne pathogenic microorganisms. Frontiers in Microbiology, 7, 1-10.

Arnau, J., Guerrero, L., Casademont, G., \& Gou, P. (1995). Physical and chemical changes in different zones of normal and PSE dry cured ham during processing. Food Chemistry, 52(1), 63-69.

Bordignon-Junior, S. E., Miyaoka, M. F., Costa, J., Benavente, C. A. T., Couto, G. H., \& Soccol, C. R. (2012). Inhibiting Gram-negative bacteria growth in microdilution by Nisin and EDTA treatment. Journal of Biotechnology and Biodiversity, 3(4), 127-135.

Brazil (2003). Ministry of Agriculture, livestock and food supply. Normative Instruction No. 62. Brasília, DF: Official journal of the union. Section, 1, 14.

Brazil (2019). Ministry of Health. National Agency of Sanitary Surveillance. Foodbourne outbreaks in Brazil - Report 2018http://portalarquivos2.saude.gov.br/images/pdf/ 2018/julho/02/Apresentacao-Surtos-DTA-Junho-2018.pdf.

Brillet-Viel, A., Pilet, M.-F., Courcoux, P., Prévost, H., \& Leroi, F. (2016). Optimization of growth and bacteriocin activity of the food bioprotective Carnobacterium divergens V41 in an animal origin protein free medium. Frontiers in Marine Science, 3, 1-13.

Camargo, A. C., de Paula, O. A. L., Todorov, S. D., \& Nero, L. A. (2016). In vitro evaluation of bacteriocins activity against Listeria monocytogenes biofilm formation. Applied Biochemistry and Biotechnology, 178(6), 1239-1251.

Chanos, P., \& Mygind, T. (2016). Co-culture-inducible bacteriocin production in lactic acid bacteria. Applied Microbiology and Biotechnology, 100(10), 4297-4308.

CLSI (2012). Methods for dilution antimicrobial susceptibility tests for bacteria that grow aerobically. CLSI document M07-A9. Wayne, PA: Clinical and Laboratory Standards Institute.

Comi, G., Andyanto, D., Manzano, M., \& Iacumin, L. (2016). Lactococcus lactis and Lactobacillus sakei as bio-protective culture to eliminate Leuconostoc mesenteroides spoilage and improve the shelf life and sensorial characteristics of commercial cooked bacon. Food Microbiology, 58, 16-22.

dos Reis, F. B., de Souza, V. M., Thomaz, M. R. S., Fernandes, L. P., de Oliveira, W. P., \& De Martinis, E. C. P. (2011). Use of Carnobacterium maltaromaticum cultures and hydroalcoholic extract of Lippia sidoides Cham. against Listeria monocytogenes in fish model systems. International Journal of Food Microbiology, 146(3), 228-234.

EFSA and ECDC (European Food Safety Authority and European Centre for Disease Prevention and Control) (2018). The European Union summary report on trends and sources of zoonoses, zoonotic agents and food-borne outbreaks in 2017. EFSA Journal, 16(12), 5500. 262 pp https://doi.org/10.2903/j.efsa.2018.5500.

Elayaraja, S., Annamalai, N., Mayavu, P., \& Balasubramanian, T. (2014). Production, purification and characterization of bacteriocin from Lactobacillus murinus AU06 and its broad antibacterial spectrum. Asian Pacific Journal of Tropical Biomedicine, 4, 305-311.

Engelhardt, T., Albano, H., Kiskó, G., Mohácsi-Farkas, C., \& Teixeira, P. (2015). Antilisterial activity of bacteriocinogenic Pediococcus acidilactici HA6111-2 and Lactobacillus plantarum ESB 202 grown under pH and osmotic stress conditions. Food Microbiology, 48, 109-115.

Field, D., Baghou, I., Rea, M., Gardiner, G., Ross, R., \& Hill, C. (2017). Nisin in combination with cinnamaldehyde and EDTA to control growth of Escherichia coli strains of swine origin. Antibiotics, 6(4), 35.

Gao, Y., Li, D., \& Liu, X. (2015). Effects of Lactobacillus sakei C2 and sakacin C2 individually or in combination on the growth of Listeria monocytogenes, chemical and odor changes of vacuum-packed sliced cooked ham. Food Control, 47, 27-31.

Gómez-Sala, B., Herranz, C., Díaz-Freitas, B., Hernández, P. E., Sala, A., \& Cintas, L. M. (2016). Strategies to increase the hygienic and economic value of fresh fish: Biopreservation using lactic acid bacteria of marine origin. International Journal of Food Microbiology, 223, 41-49.

Gursky, L. J., Martin, N. I., Derksen, D. J., Van Belkum, M. J., Kaur, K., Vederas, J. C., \& McMullen, L. M. (2006). Production of piscicolin 126 by Carnobacterium maltaromaticum UAL26 is controlled by temperature and induction peptide concentration. Archives of Microbiology, 186(4), 317-325.

Gutiérrez, S., Martínez-Blanco, H., Rodríguez-Aparicio, L. B., \& Ferrero, M. A. (2016). Effect of fermented broth from lactic acid bacteria on pathogenic bacteria proliferation. Journal of Dairy Science, 99(4), 2654-2665.

Hammes, W. P., \& Hertel, C. (2006). The genera Lactobacillus and Carnobacterium. In M. Dworkin, S. Falkow, E. Rosenberg, K. H. Schleifer, \& E. Stackebrandt (Eds.). The prokaryotes (pp. 320-403). New York: Springer.

Hammi, I., Delalande, F., Belkhou, R., Marchioni, E., Cianferani, S., \& Ennahar, S. (2016). Maltaricin CPN, a new class IIa bacteriocin produced by Carnobacterium maltaromaticum CPN isolated from mould-ripened cheese. Journal of Applied Microbiology, 121(5), 1268-1274.

Ho, V. T. T., Lo, R., Bansal, N., \& Turner, M. S. (2018). Characterisation of Lactococcus lactis isolates from herbs, fruits and vegetables for use as biopreservatives against Listeria monocytogenes in cheese. Food Control, 85, 472-483.

Huang, Y., Ye, K., Yu, K., Wang, K., \& Zhou, G. (2016). The potential influence of two Enterococcus faecium on the growth of Listeria monocytogenes. Food Control, 67, 18-24.

Hwanhlem, N., Ivanova, T., Haertlé, T., Jaffrès, E., \& Dousset, X. (2017). Inhibition of food-spoilage and foodborne pathogenic bacteria by a nisin Z-producing Lactococcus lactis subsp. lactis KT2W2L. LWT - Food Science and Technology, 82, 170-175.

Interagency Food Safety Analytics Collaboration (IFSAC). (2019). Foodborne illness source attribution estimates for 2017 for Salmonella. Escherichia coli O157, Listeria monocytogenes, and Campylobacter using multi-year outbreak surveillance data, United States (pp. 2019). GA and D.C.: U.S. Department of Health and Human Services, CDC, FDA, USDA-FSIS. https://www.cdc.gov/foodsafety/ifsac/pdf/P19-2017-reportTriAgency-508.pdf.

Iskandar, C. F., Borges, F., Taminiau, B., Daube, G., Zagorec, M., Remenant, B., \& RevolJunelles, A. M. (2017). Comparative genomic analysis reveals ecological differentiation in the genus Carnobacterium. Frontiers in Microbiology, 8, 1-14.

Koné, A. P., Zea, J. M. V., Gagné, D., Cinq-Mars, D., Guay, F., \& Saucier, L. (2018). Application of Carnobacterium maltaromaticum as a feed additive for weaned rabbits to improve meat microbial quality and safety. Meat Science, 135, 174-188.

Leisner, J. J., Laursen, B. G., Prévost, H., Drider, D., \& Dalgaard, P. (2007). Carnobacterium: Positive and negative effects in the environment and in foods. FEMS Microbiology Reviews, 31(5), 592-613.

Li, X., Li, C., Ye, H., Wang, Z., Wu, X., Han, Y., \& Xu, B. (2018). Changes in the microbial communities in vacuum-packaged smoked bacon during storage. Food Microbiology, 77, 26-37.

Lloret, E., Picouet, P. A., Trbojevich, R., \& Fernández, A. (2016). Colour stability of cooked ham packed under modified atmospheres in polyamide nanocomposite blends. LWT - Food Science and Technology, 66, 582-589.

Malheiros, P. S., Sant'Anna, V., Todorov, S. D., \& Franco, B. D. G. M. (2015). Optimization of growth and bacteriocin production by Lactobacillus sakei subsp Sakei 2a. Brazilian Journal of Microbiology, 46(3), 825-834.

Martin-Visscher, L. A., Yoganathan, S., Sit, C. S., Lohans, C. T., \& Vederas, J. C. (2011). The activity of bacteriocins from Carnobacterium maltaromaticum UAL307 against Gram-negative bacteria in combination with EDTA treatment. FEMS Microbiology Letters, 317(2), 152-159.

Masuda, Y., Perez, R. H., Zendo, T., \& Sonomoto, K. (2016). Nutrition-adaptive control of multiple-bacteriocin production by Weissella hellenica QU 13. Journal of Applied Microbiology, 120(1), 70-79.

Mathur, H., Field, D., Rea, M. C., Cotter, P. D., Hill, C., \& Ross, R. P. (2017). Bacteriocinantimicrobial synergy: A medical and food perspective. Frontiers in Microbiology, 8, $1-18$.

Metaxopoulos, J., Mataragas, M., \& Drosinos, E. H. (2002). Microbial interaction in cooked cured meat products under vacuum or modified atmosphere at $4^{\circ} \mathrm{C}$. Journal of Applied Microbiology, 93(3), 363-373.

Nilsson, L., Hansen, T. B., Garrido, P., Buchrieser, C., Glaser, P., Knøchel, S., \& Gravesen, A. (2005). Growth inhibition of Listeria monocytogenes by a nonbacteriocinogenic Carnobacterium piscicola. Journal of Applied Microbiology, 98(1), 172-183.

O'Connor, P. M., Ross, R. P., Hill, C., \& Cotter, P. D. (2015). Antimicrobial antagonists against food pathogens: A bacteriocin perspective. Current Opinion in Food Science, 2, 51-57.

de Oliveira, A. B. A., de Paula, C. M. D., Cardoso, M. R. I., \& Tondo, E. C. M. (2010). Foodborne diseases, main etiologic agents and general aspects: a review. Revista HCPA, 30(3), 279-285.

Orihuel, A., Bonacina, J., Vildoza, M. J., Bru, E., Vignolo, G., Saavedra, L., \& Fadda, S. (2018). Biocontrol of Listeria monocytogenes in a meat model using a combination of a bacteriocinogenic strain with curing additives. Food Research International, 107, 289-296 2017.

Peirson, M. D., Guan, T. Y., \& Holley, R. A. (2003). Aerococci and carnobacteria cause discoloration in cooked cured bologna. Food Microbiology, 20(2), 149-158.

Pérez, R. A., González, E. A., Agrasar, A. T., \& Guerra, N. P. (2013). A review on some important factors affecting bacteriocin production by Lactococci, Lactobacilli and Pediococci. Current Biochemical Engineering, 1(1), 9-24.

Prudêncio, C. V., Vanetti, M. C. D., \& Prieto, M. (2015). Tolerance of Salmonella enterica serovar Typhimurium to nisin combined with EDTA is accompanied by changes in cellular composition. Food Research International, 69, 281-288.

Rivas, F. P., Castro, M. P., Vallejo, M., Marguet, E., \& Campos, C. A. (2014). Sakacin Q produced by Lactobacillus curvatus ACU-1: Functionality characterization and antilisterial activity on cooked meat surface. Meat Science, 97(4), 475-479.

Sánchez-Ortega, I., García-Almendárez, B. E., Santos-López, E. M., Amaro-Reyes, A., Barboza-Corona, J. E., \& Regalado, C. (2014). Antimicrobial edible films and coatings for meat and meat products preservation. The Scientific World Journal, 2014, 1-18.

Schillinger, U., \& Holzapfel, W. H. (1990). Antibacterial activity of carnobacteria. Food Microbiology, $7,305-310$.

Sidooski, T., Brandelli, A., Bertoli, S. L., de Souza, C. K., \& de Carvalho, L. F. (2018). Physical and nutritional conditions for optimized production of bacteriocins by lactic acid bacteria - A review. Critical Reviews in Food Science and Nutrition, O(0), 1-11.

Smialek, M., Burchardt, S., \& Koncicki, A. (2018). The influence of probiotic supplementation in broiler chickens on population and carcass contamination with Campylobacter spp. - Field study. Research in Veterinary Science, 118, 312-316.

Spanu, C., Piras, F., Mocci, A. M., Nieddu, G., De Santis, E. P. L., \& Scarano, C. (2018). Use of Carnobacterium spp protective culture in MAP packed ricotta fresca cheese to control Pseudomonas spp. Food Microbiology, 74, 50-56.

Tulini, F. L., Lohans, C. T., Bordon, K. C. F., Zheng, J., Arantes, E. C., Vederas, J. C., \& De 
Martinis, E. C. P. (2014). Purification and characterization of antimicrobial peptides from fish isolate Carnobacterium maltaromaticum C2: Carnobacteriocin X and carnolysins A1 and A2. International Journal of Food Microbiology, 173, 81-88.

Vermeiren, L., Devlieghere, F., \& Debevere, J. (2004). Evaluation of meat born lactic acid bacteria as protective cultures for the biopreservation of cooked meat products. International Journal of Food Microbiology, 44(1-2), 41-45.
World Health Organization (2015). WHO estimates of the global burden of foodborne diseases: Foodborne disease burden epidemiology reference group 2007-2015. WHO Institucional repository.

Yang, E., Fan, L., Yan, J., Jiang, Y., Doucette, C., Fillmore, S., \& Walker, B. (2018). Influence of culture media, $\mathrm{pH}$ and temperature on growth and bacteriocin production of bacteriocinogenic lactic acid bacteria. AMB Express, 8(1). 